\title{
Prevention of Airborne Transmission of SARS-CoV-2 by UV-C Illumination of Airflow
}

\author{
Richard A. Bowen ${ }^{1, *}$, Peter Gilgunn ${ }^{2}{ }^{\circ}$, Airn E. Hartwig ${ }^{1}$ and Jeff Mullen ${ }^{2}$ \\ 1 Department of Biomedical Sciences, Colorado State University, 3107 Rampart Road, \\ Fort Collins, CO 80521, USA; Airn.Tolnay@colostate.edu \\ 2 Dynamics Inc., 493 Nixon Road, Cheswick, PA 15024, USA; peter.gilgunn@dynamicsinc.com or \\ peter.j.gilgunn@gmail.com (P.G.); jeff@dynamicsinc.com (J.M.) \\ * Correspondence: rbowen@colostate.edu
}

Citation: Bowen, R.A.; Gilgunn, P.; Hartwig, A.E.; Mullen, J. Prevention of Airborne Transmission of SARS-CoV-2 by UV-C Illumination of Airflow. COVID 2021, 1, 602-607. https://doi.org/10.3390/covid1030050

Academic Editor: Daniele Contini

Received: 10 October 2021

Accepted: 29 October 2021

Published: 12 November 2021

Publisher's Note: MDPI stays neutral with regard to jurisdictional claims in published maps and institutional affiliations.

Copyright: (c) 2021 by the authors. Licensee MDPI, Basel, Switzerland. This article is an open access article distributed under the terms and conditions of the Creative Commons Attribution (CC BY) license (https:// creativecommons.org/licenses/by/ $4.0 /)$.

\begin{abstract}
SARS-CoV-2 is frequently transmitted by aerosol, and the sterilization of the virus in airflows has numerous potential applications. We evaluated a UV-C illuminator similar to what might be incorporated into tubing of a mechanical ventilator for its ability to block transmission of the airborne virus from infected to naive hamsters. Hamsters protected by the UV system were consistently protected from infection, whereas non-protected hamsters uniformly became infected and displayed virus shedding and high burdens of virus in respiratory tissues. The efficiency and speed with which the virus in flowing air was inactivated using this system suggests several applications for mitigating transmission of this virus.
\end{abstract}

Keywords: COVID; SARS-CoV-2; UV disinfection; aerosol

\section{Introduction}

Severe acute respiratory syndrome coronavirus-2 (SARS-CoV-2), like several other viruses that induce serious respiratory infections, is transmitted predominantly through infectious aerosols and droplets originating from respiratory fluids of infected individuals [1-5]. The relative contribution of droplets versus aerosols to SARS-CoV-2 transmission among humans has been debated, but it appears uncontestable that aerosol transmission is a significant pathway for transmission [6,7]. In addition to these clinical observations, the stability of SARS-CoV-2 in aerosols has been demonstrated experimentally [8], and aerosol transmission of both SARS-CoV and SARS-CoV-2 from infected to naïve ferrets readily occurs $[9,10]$. Clearly, efficient and effective techniques for sterilizing airflows containing infectious aerosols would be valuable. The study reported here utilized a model for aerosol transmission of SARS-CoV-2 among hamsters to evaluate the efficacy of an ultraviolet-C (UVC) device for blocking transmission of the virus in flowing air.

\section{Materials and Methods}

Syrian hamsters between 8 and 12 weeks of age were obtained from either Envigo Corporation or Charles River Laboratories and housed on arrival in ventilated cages (Techniplast, West Chester, PA 19380, USA, Model GR900, $902 \mathrm{~cm}^{2}$ floor area) under BSL3 containment at Colorado State University. Sets of three cages were modified by drilling holes in the sides and installing flexible $22 \mathrm{~mm}$ anesthetic machine breathing tubing connecting a central cage to two peripheral cages. Each cage had two air inflow and two air outflow ports. Air outflow from the central cage and air inflow to the two peripheral cages was blocked on the rack such that air entering the central cage was forced to flow in both directions into and out of the peripheral cages (Figure 1). The airflow in this caging system comprised 75 air changes per hour. 


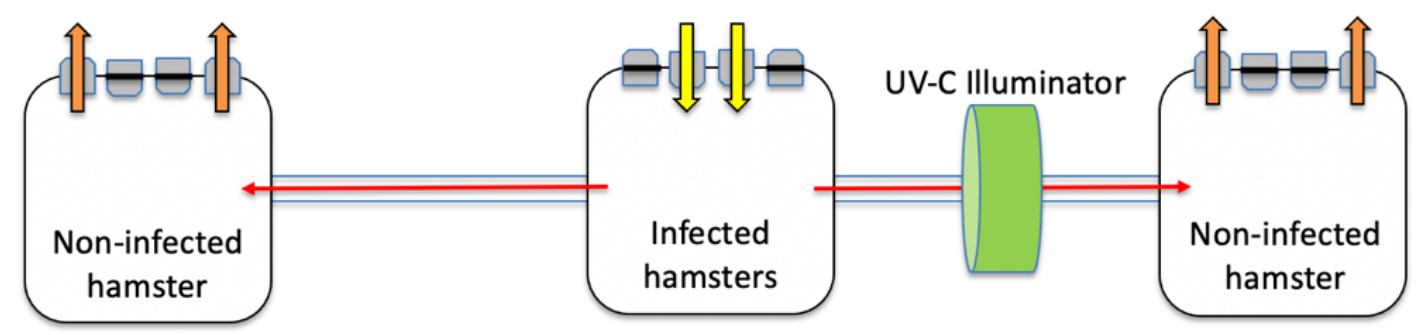

Figure 1. Cage setup for airborne transmission of SARS-CoV-2. Air inflow was blocked for the two peripheral cages and allowed for the middle cage; conversely, standard air outflow was provided for the middle cage, forcing air from that cage to flow into the two peripheral cages, thereby forcing air from the cage with virus-inoculated hamsters to flow into the two cages containing naïve hamsters. The tubing flowing into the right cage was surrounded by an array of UV-emitting lights, whereas the tubing from the central cage to the left cage was exposed only to ambient lighting. The four infected hamsters were added to the central cage one day following inoculation with SARS-CoV-2.

The device used in this experiment to perform pathogen inactivation is the core air flow channel of the Nanowave Air 300 (Dynamics Inc., Cheswick PA 15024, USA, part number PROD-000022), designed for airborne pathogen research applications (part number PRT-NWA300-C0RE-001). This device produces ultraviolet light in a UV-C range identified as optimal to inactivate bacterial and viral pathogens $(255-275 \mathrm{~nm})$. The device does not operate in wavelength ranges that produce ozone. It is comprised of a number of UV-C light sources distributed on a flexible circuit board, which is physically contorted to provide an engineered concentration of UV-C light. Additional technologies inside the device amplify the intensity of UV-C light delivered to the air flow inactivation channel. The air flow inactivation channel presents a minimal pressure drop of $0.011 \mathrm{~cm} \mathrm{H} 20$ at 30 LPM and $1.147 \mathrm{~cm} \mathrm{H} 20$ at 300 LPM along the channel. The device has an inlet and outlet connection of standard $22 \mathrm{~mm}$ tubing, independent cooling, thermal sensors, and firmware controlled over-temperature cutoffs to ensure a maximum air flow temperature of $35^{\circ} \mathrm{C}$ at a 30 LPM flow rate. The device draws a peak current of approximately 1 amp at 110 volts.

For each experiment, four hamsters in a separate cage were inoculated with the virus on day 1 by intranasal instillation of $10^{4}$ plaque-forming units (PFU) of SARS-CoV-2 (WA1/2020 isolate, Vero E6 passage 2, originally from BEI Resources NR-52281) in a volume of $0.1 \mathrm{~mL}$. On day 0 , a single naïve hamster was placed into each of the two peripheral cages, and UV-C illumination was turned on. Approximately 5 min later, oropharyngeal swabs were obtained from the four infected hamsters to confirm virus shedding, and they were introduced into the central cage. Oropharygeal swabs were collected from all hamsters on days 1, 2, and 3, with care to prevent accidental cross-contamination. Polyester swabs were rotated within the oral cavity and pharynx, then broken off in $1 \mathrm{~mL}$ of viral transport medium (Dulbecco's minimal essential medium (Sigma D1152, St. Louis, MO, USA) containing 1\% BSA (Sigma A7906), 5\% fetal bovine serum, and antibiotics (50 mg gentamycin/L and $2.5 \mathrm{mg}$ amphotericin $\mathrm{B} / \mathrm{L})$ ). The four infected hamsters from the central cage were euthanized on day 2 , and samples of turbinates, right cranial, and/or right caudal lobes of the lung were homogenized using a mixer mill (Tissuelyzer, Qiagen-Retsch, Model MM301, Santa Clarita, CA, USA) and stainless-steel balls and frozen to $-80{ }^{\circ} \mathrm{C}$ until assayed for the virus. The two hamsters in peripheral cages were euthanized on day 3 , and tissues were collected and processed similarly for virus titration. Prior to virus titration, swab samples were thawed and vortexed for 5-10 s, and tissue homogenates were thawed, vortexed, and clarified by brief centrifugation. Serial 10-fold dilutions of these samples were assayed on Vero cells using a double overlay plaque assay [11]. The limit of detection for this assay was $10 \mathrm{PFU}$ per swab and $10 \mathrm{PFU} / 100 \mathrm{mg}$ of tissue.

\section{Results}

Five replicates of the transmission-blocking experiment were conducted. In each case, each of the four infected donor hamsters in the central cage were shown to be shedding substantial amounts of virus, as assessed by virus titers in oropharyngeal swab samples, 
and three days post-infection, each of those animals had high titers of virus present in turbinates and lungs (Table 1).

For each of the five replicates, the hamster in the peripheral cage connected through the UV-C illuminator failed to become infected, as evidenced by failure to isolate the virus from three daily oropharyngeal swabs or from turbinates and lungs three days after the beginning of exposure to air from the infected hamsters. In contrast, each of the five hamsters that were unprotected by UV-C did become infected (Figure 2 Table 1).

A. Infected

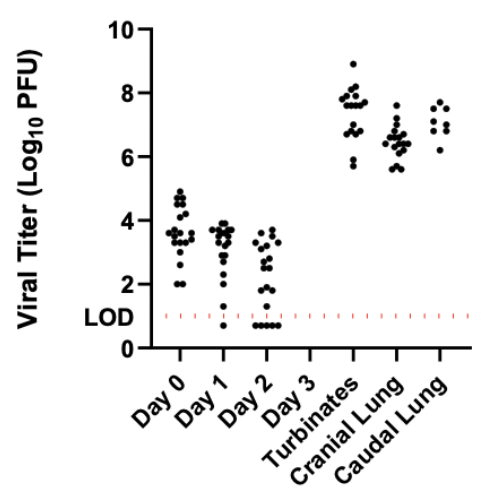

B. Unprotected

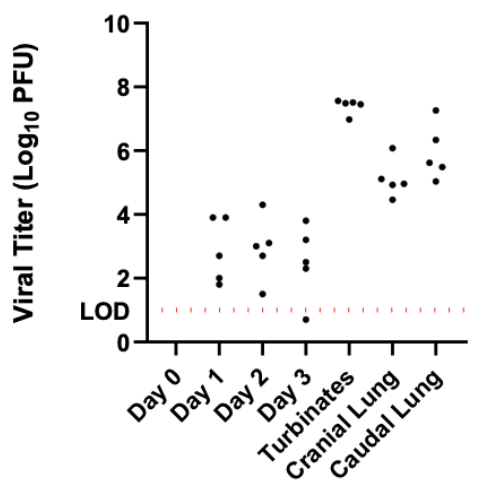

C. Protected

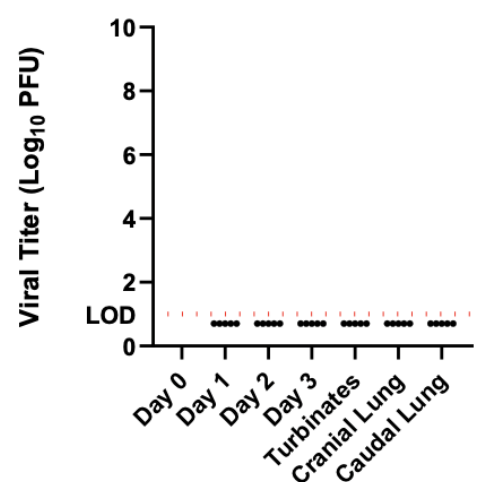

Figure 2. Virus titers in oropharyngeal swabs and tissues over all five replicates. Titers are presented as log10 plaqueforming units (PFU) per swab or per $100 \mathrm{mg}$ of tissue. (A) Hamsters deliberately infected on day 1; (B) hamsters exposed to airflow from infected hamsters without UV-C protection; (C) hamsters exposed to airflow from infected hamsters and protected by UV-C illumination around airflow conduit. 
Table 1. Virus titers in oropharyngeal swabs and tissues collected from infected and recipient hamsters.

\begin{tabular}{|c|c|c|c|c|c|c|c|c|}
\hline & & $\log _{10}$ PFU & $\log _{10}$ PFU & $\log _{10}$ PFU & $\log _{10}$ PFU & $\log _{10}$ PFU per & $\log _{10}$ PFU per & $\log _{10}$ PFU per \\
\hline & & per Swab & per Swab & per Swab & per Swab & $100 \mathrm{mg}$ Turbinates & $\begin{array}{c}100 \text { mg Cranial } \\
\text { Lung }\end{array}$ & $\begin{array}{c}100 \text { mg Caudal } \\
\text { Lung }\end{array}$ \\
\hline Replicate & Treatment & Day $^{1} 0$ & Day 1 & Day 2 & Day 3 & Day 3 & Day 3 & Day 3 \\
\hline 1 & Infected control 1 & 3.28 & 3.34 & 2.20 & ND & 7.58 & 7.59 & ND \\
\hline 1 & Infected control 2 & 4.23 & 3.72 & $<1.0$ & ND & 8.86 & 6.36 & ND \\
\hline 1 & Infected control 3 & 3.32 & 1.30 & $<1.0$ & ND & ND & ND & ND \\
\hline 1 & Infected control 4 & 3.58 & $<1.0$ & $<1.0$ & ND & ND & ND & ND \\
\hline 1 & Unprotected & ND & 1.78 & 1.48 & $<1.0$ & 6.98 & 4.93 & 5.62 \\
\hline 2 & Infected control 1 & 1.95 & 2.75 & 2.72 & ND & 8.20 & 7.20 & 7.53 \\
\hline 2 & Infected control 2 & 3.71 & 2.90 & 3.56 & ND & 6.96 & 6.23 & 7.51 \\
\hline 2 & Infected control 3 & 4.89 & 3.58 & 3.49 & ND & 6.72 & 6.96 & 7.15 \\
\hline 2 & Infected control 4 & 3.56 & 3.54 & 3.15 & ND & 5.91 & 6.59 & 7.68 \\
\hline 2 & UV-C protected & ND & $<1.0$ & $<1.0$ & $<1.0$ & $<1.0$ & $<1.0$ & $<1.0$ \\
\hline 2 & Unprotected & ND & 2.04 & 4.32 & 3.79 & 7.45 & 4.96 & 5.49 \\
\hline 3 & Infected control 1 & 3.49 & 3.18 & $<1.0$ & ND & 6.79 & 5.67 & ND \\
\hline 3 & Infected control 2 & 3.62 & 3.28 & $<1.0$ & ND & 6.68 & 5.57 & ND \\
\hline 3 & Infected control 4 & 4.15 & 2.04 & $<1.0$ & ND & 6.76 & 6.15 & ND \\
\hline 3 & UV-C protected & ND & $<1.0$ & $<1.0$ & $<1.0$ & $<1.0$ & $<1.0$ & $<1.0$ \\
\hline 3 & Unprotected & ND & 2.68 & 3.04 & 3.18 & 7.49 & 6.08 & 5.04 \\
\hline 4 & Infected control 1 & 2.58 & 3.69 & 1.90 & ND & 8.15 & 6.45 & ND \\
\hline 4 & Infected control 2 & 1.95 & 3.72 & 3.23 & ND & 7.93 & 6.40 & ND \\
\hline 4 & Infected control 3 & 3.40 & 3.52 & 1.85 & ND & 7.59 & 6.41 & ND \\
\hline 4 & Infected control 4 & 3.04 & 3.71 & 2.52 & ND & 7.83 & 6.32 & ND \\
\hline 4 & UV-C protected & ND & $<1.0$ & $<1.0$ & $<1.0$ & $<1.0$ & $<1.0$ & $<1.0$ \\
\hline 4 & Unprotected & ND & 3.94 & 2.68 & 2.26 & 7.56 & 4.46 & 6.34 \\
\hline 5 & Infected control 1 & 4.69 & 3.87 & 2.49 & ND & 7.59 & 6.79 & 6.77 \\
\hline 5 & Infected control 2 & 4.49 & 2.90 & 3.34 & ND & 7.93 & 6.74 & 6.20 \\
\hline 5 & Infected control 3 & 4.73 & 3.63 & 2.79 & ND & 7.63 & 6.58 & 7.04 \\
\hline 5 & Infected control 4 & 4.49 & 3.94 & 1.85 & ND & 7.71 & 6.61 & 6.76 \\
\hline 5 & UV-C protected & ND & $<1.0$ & $<1.0$ & $<1.0$ & $<1.0$ & $<1.0$ & $<1.0$ \\
\hline 5 & Unprotected & ND & 3.91 & 3.08 & 2.46 & 7.51 & 5.11 & 7.26 \\
\hline
\end{tabular}

${ }^{1}$ Day 0 refers to the day after infection of the control hamsters and the day airflow to peripheral cages was initiated. 


\section{Discussion}

UV inactivation has a long history as a means for inactivating pathogens [12], more recently, including a number of human coronaviruses [13-15]. In a large fraction of these studies, virus inactivation was evaluated in liquid medium rather than aerosols. Moreover, UV-based air purifiers are readily available and UV-based sterilization of room air has been repeatedly advocated $[16,17]$. One prominent application of UV light sterilization of airflow is in protecting healthcare workers during manual or mechanical ventilation $[17,18]$, and the apparatus evaluated in these experiments was a prototype for such a system. However, the same technology can readily be scaled to accommodate much larger conduits, such as ventilation ducts [19].

In the current experiments, a single test hamster was placed in each peripheral cage; because hamsters readily transmit SARS-CoV-2 to one another through contact, our goal was to have the hamster exposed to virus strictly by aerosol. The results we obtained for each of the five replicates of this experiment were highly consistent: in each case, the recipient hamster receiving air from the cage housing infected hamsters that flowed through the UV-C illuminator failed to become infected, while each of the five hamsters that received air that had not been illuminated were rapidly infected and had virus shedding and tissue burdens of virus similar to intranasally infected controls. Although the results indicate that this method of inactivating viruses in airflows is highly effective, and the efficacy of inactivation likely is not influenced by the source of the virus, a small number of animals were evaluated, and additional validation of the procedures will require direct testing with infected humans. The results presented here support an initial application of equipping mechanical ventilators with UV inactivation devices to provide protection above standard personal protective equipment to attending healthcare workers.

\section{Patents}

Dynamics Nanowave Air 300 utilizes flexible electronics related to over 100 pending and issued patents by Dynamics Inc., with over a dozen pending patent applications related to high-intensity UV generation for airborne pathogens.

Author Contributions: Conceptualization, R.A.B., P.G. and J.M.; methodology, R.A.B., P.G., A.E.H. and J.M.; writing—original draft preparation, R.A.B.; writing-review and editing, R.A.B., P.G., A.E.H. and J.M. All authors have read and agreed to the published version of the manuscript.

Funding: This research received no external funding.

Institutional Review Board Statement: All experiments were approved by the Colorado State University Institutional Animal Care and Use Committee under approval 1279 and Institutional Biosafety Committee approval 20-112B.

Informed Consent Statement: Not applicable.

Data Availability Statement: Not applicable.

Acknowledgments: We thank Rachel Maison for graphics support.

Conflicts of Interest: The authors declare no conflict of interest. Two of the authors (Gilgunn and Mullen) are or were employees of Dynamics, Inc. and were involved in the design and construction of the device under test.

\section{References}

1. Kulkarni, H.; Smith, C.M.; Lee, D.D.H.; Hirst, R.A.; Easton, A.J.; O'Callaghan, C. Evidence of respiratory syncytial virus spread by aerosol: Time to revisit infection control strategies? Am. J. Respir. Crit. Care Med. 2016, 194, 306-316. [CrossRef] [PubMed]

2. Kim, S.H.; Chang, S.Y.; Sung, M.; Park, J.H.; Kim, H.B.; Lee, H.; Choi, J.-P.; Choi, W.S.; Min, J.-Y. Extensive viable Middle East respiratory syndrome (MERS) corona- virus contamination in air and surrounding environment in MERS isolation wards. Clin. Infect. Dis. 2016, 63, 363-369. [CrossRef] [PubMed]

3. Li, Y.; Qian, H.; Hang, J.; Chen, X.; Cheng, P.; Ling, H.; Wang, S.; Liang, P.; Li, J.; Xiao, S.; et al. Probable airborne transmission of SARS-CoV-2 in a poorly ventilated restaurant. Build. Environ. 2021, 196, 107788. [CrossRef] [PubMed] 
4. Greenhalgh, T.; Jimenez, J.L.; Prather, K.A.; Tufekci, Z.; Fisman, D.; Schooley, R. Ten scientific Reasons in Support of Airborne Transmission of SARS-CoV-2. Lancet 2021, 397, 1603-1605. [CrossRef]

5. Nissen, K.; Krambrich, J.; Akaberi, D.; Hoffman, T.; Ling, J.; Lundkvist, A.; Svensson, L.; Salaneck, E. Long-distance airborne dispersal of SARS-CoV-2 in COVID-19 wards. Sci. Rep. 2020, 10, 15895. [CrossRef]

6. Morawska, L.; Milton, D.K. It Is Time to Address Airborne Transmission of Coronavirus Disease 2019 (COVID-19). Clin. Infect. Dis. 2020, 71, 2311-2313. [CrossRef] [PubMed]

7. Johansson, M.A.; Quandelacy, T.M.; Kada, S.; Prasad, P.V.; Steele, M.; Brooks, J.T.; Slayton, R.B.; Biggerstaff, M.; Butler, J.C. SARS-CoV-2 Transmission from People Without COVID-19 Symptoms. JAMA Netw. Open 2021, 4, e2035057. [CrossRef] [PubMed]

8. Van Doremalen, N.; Bushmaker, T.; Morris, D.H.; Holbrook, M.G.; Gamble, A.; Williamson, B.N.; Tamin, A.; Harcourt, J.L.; Thornburg, N.J.; Gerber, S.I.; et al. Aerosol and Surface Stability of SARS-CoV-2 as Compared with SARS-CoV-1. N. Engl. J. Med. 2020, 382, 1564-1567. [CrossRef] [PubMed]

9. Richard, M.; Kok, A.; de Meulder, D.; Bestebroer, T.M.; Lamers, M.M.; Okba, N.M.A.; van Vlissingen, M.F.; Rockx, B.; Haagmans, B.L.; Koopmans, M.P.G.; et al. SARS-CoV-2 is transmitted via contact and via the air between ferrets. Nat. Commun. 2020, 11, 3496. [CrossRef] [PubMed]

10. Kutter, J.S.; de Meulder, D.; Bestebroer, T.M.; Lexmond, P.; Muldevs, A.; Richard, M.; Fouchier, R.; Herfst, S. SARS-CoV and SARS-CoV-2 are transmitted through the air between ferrets over more than one meter distance. Nat. Commun. 2021, $12,1653$. [CrossRef] [PubMed]

11. Jia, Q.; Bielefeldt-Ohmann, H.; Maison, R.; Masleša-Galić, S.; Cooper, S.K.; Bowen, R.A.; Horwitz, M.A. Replicating bacteriumvectored vaccine expressing SARS-CoV-2 Membrane and Nucleocapsid proteins protects against severe COVID-19-like disease in hamsters. NPJ Vaccines 2021, 6, 47. [CrossRef] [PubMed]

12. Reed, N.G. The history of ultraviolet germicidal irradiation for air disinfection. Public Health Rep. 2010, 125, 15-27. [CrossRef] [PubMed]

13. Buonanno, M.; Welch, D.; Shuryak, I.; Brenner, D.J. Far-UVC light (222 nm) efficiently and safely inactivates airborne human coronaviruses. Sci. Rep. 2020, 10, 10285. [CrossRef] [PubMed]

14. Raeiszadeh, M.; Adeli, B. A critical review on ultraviolet disinfection systems against COVID-19 outbreak: Applicability, validation, and safety considerations. ACS Photonics 2020, 7, 2941-2951. [CrossRef]

15. Chiappa, F.; Frascella, B.; Vigezzi, G.P.; Moro, M.; Diamanti, L.; Gentile, L.; Lago, P.; Clementi, N.; Signorelli, C.; Mancini, N.; et al. The efficacy of ultraviolet light-emitting technology against coronaviruses: A systematic review. J. Hosp. Infect. 2021, $114,63-78$. [CrossRef] [PubMed]

16. Nardell, E.A. Air disinfection for airborne infection control with a focus on COVID-19: Why germicidal UV is essential. Photochem. Photobiol. 2021, 97, 493-497. [CrossRef] [PubMed]

17. Phua, G.-C.; Govert, J. Mechanical ventilation in an airborne epidemic. Clin. Chest Med. 2008, 29, 323-328. [CrossRef] [PubMed]

18. Ferioli, M.; Palange, P.; Nava, S. Protecting healthcare workers from SARS-CoV-2 infection: Practical indications. Eur. Respir. Rev. 2020, 29, 200068. [CrossRef] [PubMed]

19. Srivastava, S.; Zhao, X.; Manay, A.; Chen, Q. Effective ventilation and air disinfection system for reducing Coronavirus Disease 2019 (COVID-19) infection risk in office buildings. Sustain. Cities Soc. 2021, 75, 103408. [CrossRef] [PubMed] 